\title{
Relational Inquiry-Attending to the Spirit of Nursing Students
}

\author{
Michelle Spadoni * and Patricia Sevean * \\ School of Nursing, Lakehead University, 955 Oliver Rd, Thunder Bay, ON P7B 5E1, Canada \\ * Correspondence: mmspadon@lakeheadu.ca (M.S.), psevean@lakeheadu.ca (P.S.); Tel.: +1-807-343-8667 \\ Academic Editors: Fiona Timmins and Wilf McSherry \\ Received: 19 December 2015; Accepted: 23 February 2016; Published: 21 March 2016
}

\begin{abstract}
The impetus for this paper came from our experiences as learner-teachers of re-considering the epistemological and ontological roots of our undergraduate-nursing curriculum. It began as an earnest dialogue regarding particular aspects of first year undergraduate-nursing theory content, specifically, caring and compassion, self-concept and nursing identity, spirituality and culture, a simple question-how could we better engage first year nursing students with what they frequently considered to be "abstract" and "soft" concepts? An organic need to be "good teachers" and introduce learners to fundamental concepts in nursing, and have them understand, in meaningful ways, the complexity of "caring and compassion" with respect to what it is that nurses do, think, and enact. To this end, we enlisted Relational Inquiry, as articulated by Gweneth Hartrick Doane and Colleen Varcoe, as a means of creating an epistemological and ontological foundation for our teaching practice in order to better support the development of critically reflective, community orientated, caring relational practitioners. Initially, we thought relational inquiry was an epistemological endeavor and found that it is an ontological undertaking. We discovered that practicing from a relational caring perspective shifted our focus from the content to the student as a developing practitioner and human being. Through the process of re-imagining our teaching practice, we have begun to re-consider the importance of "attending to the spirit" of nursing students.
\end{abstract}

Keywords: spirituality; relational inquiry; nursing education; hermeneutics; story-telling

\section{Introduction}

Teaching first year undergraduate nursing students is a privilege; and it comes with a sense of obligation and responsibility to do, and to know how to be a "good teacher". First year undergraduate students enter the academia with a sense of anticipation, uncertainty, excitement, and hope. They come to us from many different backgrounds and stages of development, with a rich cache of life experiences. As they step into the lecture theatre for the first time, watching them find their seats, you see their eyes searching for some sense of familiarity, safety, comfort, and connection; one feels the momentous nature of that moment for them. It may have something to do with the possibilities that exist in the human spirit, at the individual and collective levels of community. It is a point of transition and transformation, which holds ample potential, as students meet for the first time. It is but a moment in time that you can miss in a blink, yet, if you just take a breath and let it seep in, you can feel to your very toes an intense energy washing over "us" (students and teachers) as "we" become something bigger then any single one of us. Letting the energy wash over us, and giving into the momentum of being caught up in the sound of nervous laughter, soft sighs, voices asking "can I sit here", "oh sorry I stepped on your foot", and even the sounds made by the plunking down of pursues, computer, and book bags, as people settle in, indicates a new beginning bubbling up before our eyes. A wonderful chaotic sense of the unknown and the overwhelming energy of building anticipation for what might be. 
As a teacher, you cannot help but feel the energy that resonates from this "anticipation"; it envelops you, just as surely as an old comfortable sweater, and it vibrates in your very cells. It is humbling. It brings to the forefront one's sense and recollection of transitioning and uncertainty, hope and worry,- - the aching need of wanting to be a "good student" and a "good teacher", and, at the same time, the niggling fear of self doubt and failure. Malidoma Some suggests that "You cannot be who you truly are until you can put what you remember into action in your life"([1], p. 309). A silent message that resonates in your heart and mind as a teacher: that learning-teaching is a spiritual act; an ontological way of being in the world, which asks something of us and appreciates the synergistic nature of knowing and unknowing, of hope and loss, of experience lived over and over. "Until you can put what you remember into action in your life" [1] - compels us to recall, as a teacher, that one can only come to full fruition when one has embodied knowing/unknowing in such a way that one's very way of being with learners moves beyond one's sense of self, and resonates inwards and outwards. An energy vibrating "between" that "attends to the spirit" [2] by recognizing the possibility that we might sense the "other" (learners) otherness, in a manner that enlightens the full potential of the other's spirit, of their very being. If we hold open that spiritual and energetic space within and between -we may both (as learners) discover something about our inner world, and about our place at this moment in time, here together: our experiences, our strengths, potentialities as human beings, and as developing nurses.

If we can awaken in students their own spirituality, then, in turn, we can enhance through spiritual pedagogy their ability to assess and support the spiritual aspects of the lives of their patients/families/colleagues. Research has shown that as "nurses' awareness of their own spirituality improves, so too does their ability to deliver spiritual care" ([3], p. 961). If we believe in holistic nursing care, then care includes the spiritual dimension: "So as nurses, if we claim to give holistic care, we must pay attention to this spiritual dimension" ([4], p. 103). Therefore, as educators, we need to be concerned with teaching and learning approaches that unearth how caring and compassion, kindness, human love and forgiveness (all aspects of spiritual self) are taught [5]. What would happen if we thoughtfully cultivated the spiritual nature of our lives in the classroom with learners, and let spirituality be the root of our practice as learner-teachers-would our time "here together" be about transformation-would it make us better people in the world together?

\section{Remembering-The Impetus for this Paper}

Looking back at our experience of re-considering the epistemological and ontological nature of our learning-teaching practice, we have pondered why spirituality in contemporary nursing has been constructed in such a way as to objectify it as an abstract concept to be studied in relation to cultural safe nursing practice, and/or one of the dimensions of nursing knowledge typically associated with mental health within entry to practice guidelines [6]. We wondered if we were unconsciously thinking apart our wholeness. Do we think of spirituality as an aspect of individuality, but somehow separate from our collective learning-teaching lives and professional identity? Do we shed it like an old beloved sweater, an article of clothing that we remove (or cover) before entering the classroom, never truly disclosing it in any visible manner? Left behind in the confines of our office, perhaps in fear that it might influence or prejudice the learner's evolving understanding of spirituality. And/or perhaps, spirituality is subtle, lived out in nuances, not necessarily surfacing in any visible way in our everyday administrative teaching encounters. We wondered if, on some level, we deconstruct ourselves, compartmentalizing bits and pieces of our self in order to become the "teacher", remnants, perhaps, of Descartes' Cartesian dualism. If the self is sought in: "some inward domain, popularly called 'consciousness'. If the self-or identity, or personhood-is conceived to be primarily inner and spiritual, it can be thought of as inviolable" ([7], p. 11). Do we need to come to terms with the tension that resides between our inner and outer world, in order to gain a deeper understanding of what it means to be in relationship with 'others' and the world we live in-to see beyond our self, in order to understand how the realities of our life shape our way of being in the world [7]? It 
would seem that what we have been longing for is a means of re-envisioning what lies "beyond the physical, psychological, and social health" so that they/we might "attend to the spirit", as Hartrick Doane and Varcoe suggest, and "see the strength and life force that constitutes, inspires and shapes" them/us ([2], p. 78). As human beings, we recognize that the resiliency inherent in the human spirit lies in the heart-mind-soul of each and every one of us, and "speaks to the human condition and our ability to rally from trauma, illness, and hardship; overcome vulnerabilities; cope and deal with problems, meet life's challenges, and finding meaning in living"' ([8], p. 4). As nurse educators, we acknowledge the sacred task of nurturing the learning spirit within students, recognizing the capacity within each individual to be present and bear witness to the human suffering of others, feel empowered to take hold of those situations, and to thrive and grow spiritually through the "shared experience" of battling adversity with others. It is our view that, when nurses' become aware of their own spirituality, "their ability to deliver spiritual care" grows ([3], p. 961).

\section{Situating Self-Personal Recollections (Michelle and Pat)}

We teach in a Canadian university. Lakehead University's School of Nursing has just recently celebrated its fiftieth anniversary. The university is located on the traditional lands of the Anishinaabe people, who are signatories of the Robertson-Superior treaty, particular of Fort William First Nations. At any given time, 700-800 students are enrolled in the baccalaureate nursing program, with approximately 200 students entering the first year of the program. We have just been through the process of curriculum renewal and have began to teach a new curriculum based on relational inquiry, as articulated by Gweneth Hartrick Doane and Colleen Varcoe, [2,9]

\subsection{Remembering and Forgetting}

Lewis Carroll suggested: "It's a poor sort of memory that only works backwards" ([10], p. 45), the Queen remarked (Through the Looking-Glass and What Alice Found There). The memories we recall within our stories are interwoven within a larger tapestry-the stories of our lives, you might say "nested". They do not live "alone", as Calasso reflects: "Stories never live alone: they are the branches of a family that we have to trace back, and forward" ([11], p. 8). In order to interpret stories, we need to reclaim the contextual relations of time and place in which the stories occurred [12]. Thus, Jardine suggests that the dialectic nature of memory and forgetting-

"is part of what constitutes the building of character, what constitutes the great and terrible human enterprise of becoming someone." And Bildung: "I become someone because of what I have been through, what I have endured in losing and gaining, in remembering and forgetting, in venture and return" ([12], p. 271).

Michelle-It is strange the things we hold on to over the years. For some reason tucked away in my files I have kept the course outlines and corresponding note pages from my first year nursing classes. Retrospectively, the nursing course outlines seem more like a table of content in my narrative of being and becoming a nurse during the late 1970's and early 1980's. I recall that "spirituality" as a "concept" was not covered in theory classes, nor was it defined. Neither was religion discussed, outside of a lecture on the historical development of nursing, where reference was made to the contribution of religious orders in the French colonies and prairie settlements in Canada. As well, "spirituality" (but not "faith") was covered in the same $2 \mathrm{~h}$ lecture, linked to: "vocation" and "calling". As a student, given the lack of focus and/or purposeful dialogue about the meaning of spirit, spirituality, faith, and religion in our nursing classes, I was left with the discrete impression that these particular aspects of one's life belonged to one's private life and did not enter public life in a meaningful way, and were not an overt aspect of professional identity. In my generation it could broadly be stated that higher education settings were secular. I entered nursing in a time where there was a distinct separation of church and state, where "religion is often understood as belonging to the private (vs. public) sphere" ([13], p. E4). However, today there are nursing scholars who suggest: 
Nursing, along with other practice and academic disciplines is (re) engaging with religion. Following several decades of focusing on spirituality as a generic and universal experience, with an accompanying tendency to disparage religions, nursing scholarship is shifting to encompass both spirituality and religion ([13], p. E1).

Today, I look down and read the course outline with the eyes of a seasoned practitioner (advanced practice nurse, teacher, and researcher). As a teacher I recognize that curriculum is not static like the yellowed pages I hold in my hands. Curriculum is so much more. It is about growth and development, human formation and capacity, community, ethics, knowledge translation, competencies and skills, moral sensibilities, epistemology and philosophy, learning objectives, outcomes, and evaluation processes; internal and external forces. Organizational and institutional policies and procedures, financial systems (internal forces) and standards of professional practice and legislation, professional and licensing organizations, societal and world pressures, politics and social policies (external forces).

From a historical perspective I was taught that the nursing profession in Canada evolved from the work of women caring for family and friends in early settlements. As settlement areas became more organized hospitals were built. In Quebec the role of religious orders was significant to the training of "nurses" both in hospitals and in the community setting; in what we now recognize as Ontario, the Nightingale model of nursing was an important aspect in the development of hospital nursing [14]. At different points in time, over the lifespan of the profession in Canada, nursing has been/is viewed by some to be a "spiritual vocation" [14]. During my time as a student, nurse theorists (e.g., Jean Watson, Betty Neuman) were writing about the concept of spirituality, but their work was not a focus in our school's curriculum.

Returning to the course outline and corresponding note pages, Florence Nightingale was introduced as a "historical nursing figure". Her articulation of nursing/nursing care and the knowledge required to nurse contributed to the development of the profession of nursing. On the note page I underlined Nightingale and added to my homework writing log: "an example of the profession's connection to Christianity", followed by-"nursing-a spiritual calling". Although the discussion of Florence Nightingale was brief, I had copied Nightingale's articulation of nursing cited by our teacher in class:

Nursing is an art, and if it is to be made an art, it requires as exclusive a devotion, as hard a preparation, as any painter's or sculptor's work. For what is having to do with dead canvas or cold marble compared with having to do with the living body, the temple of God's spirit ([15], p. 13).

"Nursing is an art ... devotion" I underlined with an arrow pointed back to "nursing-a spiritual calling". During my first clinical placement I worked on a surgical unit, along side a senior surgical nurse. I remember thinking that watching her attend to the needs of her patients was like watching a well-choreographed dance-it was an art. She was able to move back and forth responding intuitively. I asked her how she knew what was coming? In my clinical communication journal (18 September 1981) I recorded key messages from our conversation: "when you first start to practice it is hard because you are trying to remember everything you are taught in class", and that at "first you have to think carefully about everything you do, preparing an injection, how to give it" [16]. "But, as you learn to practice, you learn that your patients are also teaching you" [16]. She noted: "as you learn to apply your knowledge in moments of taking care of your patient, what you know becomes part of you" [16]. She ended her explanation with "then you can truly see the patient-the person in front of you, see their energy. That is when you will really be there for them. It really is the spirit of what we do" [16]. I have not forgotten her. She remains visible in my memory. I not only observed her "devotion" but I was a recipient of her "devotion" as a student, it was in her way of "being" with patients, students and colleagues, her spirit. Years later, in the course of my doctoral work I turned to the writings of Sister Simone Roach and her explanation of caring, and once more considered the meaning of "spirit" [5]. Her words made me pause; re-think what it means to attend to the spirit of 
nursing students: "Caring is the means, the medium, the mode through which the human being is a being-in-the world" ([5], p. 2).

In the early 1980's competency-based practice and the use of nursing diagnosis and nursing care plans was just emerging, and was a central discussion in the classroom and in the clinical setting. Science and technology were forefront in healthcare settings and subsequently in nursing classrooms. For example, on the clinical units at the end of every shift we filled in "acuity" indicators based on the patient's medical diagnosis, and nursing diagnosis. Under nursing diagnosis, specific activities were tracked (e.g., number of oral medications, intravenous medications and hydration, dressings, number of times vital signs were taken, and so forth). The focus was shifting, slipping away from nursing as "art and science" towards nursing as a "science".

Pat-I am first and foremost a nurse. My earliest memories are of being hospitalized at the age of four with an acute episode of otitis media which was treated with penicillin and tender loving care. My favorite nurse bathed me, touched me gently, gave me hope and treated me with human dignity and kindness. Without that precious parcel of caring I am not sure if my spirit would have survived. Truly restorative human care transactions between a nurse and another individual can best be described as "a coming together and establishment of contact between persons; one's mind-body-soul engages with another's mind-body-soul in a lived moment" ([17], p. 47). My spirit had been replenished and when I was discharged home I knew firmly in my four year-old mind who and how I wanted to be in my life-I wanted to live in that spiritual transpersonal communion between the caregiver and the one being cared for. Over 45 years ago I embarked on a journey to being and becoming a nurse by obtaining my diploma in nursing. When I was a nursing student I was inspired by the words of Virginia Henderson, she believed nurses should "get into the skin" of each of their patients in order to understand what he/she needs [18]. Once I grasped onto that concept I then became set on a path that involved stepping out of my personal frame of reference and into the other's frame of reference. Once you truly attune yourself to the needs of another you understand their strengths and limitations, what their needs are and you can harness your own powers and knowledge to analyze, synthesize and translate knowledge into thoughtful nursing actions that respect and support the human spirit of the other [8]. Mid-career after completing both nursing and education degrees my focus shifted to being a clinical nurse educator and teaching students about anatomy, physiology and diseases. One day on my rounds seeing students I stopped to have a conversation with a former students now a new graduate nurse who said to me (personal diary entry, 30 October 1990)

I learned a lot from your post-conferences when you got off topic and told stories about patients you cared for in the past, mistakes you made and how you would approach it differently the next time; I liked it when you suggested we care for patients as if they were our family, or someone equally as important to us. I like the diaries you encouraged us to keep and share and when I read it over later I could see how far I had come [19].

At that moment I became acutely aware of the gift I was being given by my former student and it renewed my teaching-soul, reminding me to focus more closely on those teachable moments in practice when human spirits move together discovering each other more fully. Later in my doctoral work, I became inspired by the work of Dewey [20] who defined the art of teaching as being in community, lived experience, and how persons relate with one another; and Greene's [7] suggestion that artful practice is about human understanding and how people experience life, reflect on themselves, make sense of their own situations, and change their actions accordingly. Two key perspectives emerged in my teaching practice, namely, (a) a social-justice focus through consciousness raising and; (b) an approach using rational thought and reflection as part of collaborative learning experiences. As a result, narratives became soul-based teaching/learning opportunities intuitive, holistic and contextually based. 


\subsection{The Momentum of Remembering and Forgetting}

We (Pat and Michelle) are both advanced practice nurses with backgrounds in oncology. Through our many years of nursing, we have supported patients, families, and colleagues through critical times in their life. We have witnessed and participated in moments of attending the spirits of our patients: being invited to pray with a patient who faces a health crisis, invited to witness sacraments being given. We have entered the sacred, when being asked by family members to assist in the "ceremony" of dressing their loved one in the last hour of life, because, within their religious beliefs, the body cannot be washed or changed after the person takes their last breath. We have sat at a bedside and held a person's hand witnessing their passing, knowing that their children cannot get there in time. Thus, practice has taught us that spirit, spirituality, faith, and religion are complicated, sometimes (not always) interwoven, not easily defined, manifested in many different ways. It would seem an essential aspect of people's lives and ways of "being, knowing, and doing".

Today we can turn to the work of nurse historians to shed light on the connections being made between spirituality, nursing history, and nursing image in relation to the meaning of nursing practice and the formation of the profession in Canada. There are those who suggest the profession's roots begin within the unpaid work of women taking care of friends and family [21]. Even as nursing transitioned from unpaid work to a paid occupation, nurses continued to be seen as embodying: "seemingly universal characteristics of feminine healing, caring, and nurturing" ([21], p. 1). McPherson suggests the word "nurse" brings forth, images of maternal caring so often aligned with our understanding of human existence and to the very life of women [21]. From this context, consider the following 1898 hospital promotional manual describing the characteristics of a "good nurse" in relational to contemporary nursing practice, taking into consideration the time period and language used, we find that aspects of the message still resonate ([14], p. 10):

Love of God and of fellow creatures

Strength of body and mind.

Cheerfulness.

Belief that cleanliness is next to godliness.

Refinement of character.

Good education.

Knowledge of human nature.

Quickness of comprehension and action

Patience and perseverance.

In 1995, the Canadian Nurses Association completed the first national level study assessing the inclusion/exclusion of spirituality in Canadian undergraduate nursing education, noting at the time that there appeared to "be no studies examining how the spiritual dimension is addressed in Canadian nursing education" ([22], p. 98). The results shed light on the complex tensions surrounding the inclusion of spirituality in nursing curriculum. The authors suggested that while nurses recognized the spiritual needs of patients as important to patient overall well-being, nurses noted that spirituality was "minimally addressed" in nursing education ([22], p. 98). There was uncertainty about "introducing "non-scientific", spiritual realm into science-based nursing care" ([22], p. 98). Utilizing an exploratory descriptive design, data was gathered from undergraduate faculties across the country. At the time, $66.6 \%$ of respondents indicated that the term spiritual dimension (as articulated by the researchers) was not defined in their education program [22]. Those that did include spiritual dimension within their curriculum either encouraged students and faculty to personally define spirituality, and/or included the work of nurse theorists: Jean Watson [17] and Betty Neuman within their curriculum [23]. The authors captured some of the tensions and difficulty (at the time) of not only defining spirituality but of 
the ways in which the inclusion of spiritual dimension was introduced and/or included/excluded in curriculum: "I believe there is some inconsistency in our faculty; we have the tendency to believe that spirituality is a private matter yet we see its importance in a person's health" ([22], p. 101). The authors also provided insight into the confusion related to terms: spiritual dimension, spirituality, and religion- "I' $m$ not sure if nurses should promote spiritualism. Probably nurses should acknowledge and accept the client's perspective. Nurses should certainly not promote religions" ([22], p. 101). Notably, 77.8\% could not identify specific learning objectives related to spirituality. Although this study was done in 1995, what is captured to varying degrees is the powerful influence of secularism in educational settings and how the separation of church and state shape, in different ways, educators: focus, discussions, understandings/meanings, beliefs and values-"spirituality is a private matter"; "Nurses should certainly not promote religions" ([22], p. 101).

Canada can be characterized as a liberal-democratic state, which secularizes public life "so that the role of religion/spirituality in public life has been de-emphasized" ([24], p. 153). The separation of church and state relegates religion and spirituality to the private sphere and has created uncertainty about where religion and spirituality fit within education and healthcare [13]. From a nursing perspective:

Secularism, with associated emphases on rationality and scientism and critiques of the detrimental ideological and political roles of religion in society, has a strong hold on health sciences and services, through the 1960s to today. With religion largely sidelined, spirituality discourses have taken root more recently, beginning in the 1980s and typically reflecting New Age or post-Christian affinities ([25], p. 251).

In nursing while there has been a great deal of time and effort spent trying to define and/or describe spirituality, there still remains "inadequacies of nursing's use of the concept of 'spirituality' to the near exclusion of 'religion'"' ([25], p. 251). In other disciplines, like sociology, the focus has been exploring how spirituality and religion "are 'lived'" ([25], p. 251). Reimer Kirkham notes that, in nursing, religion has been subsumed under the concept of spirituality, while it has been the reverse for disciplines like sociology. Furthermore, suggesting that in nursing spirituality has been conceptualized and/or understood as "apolitical" and to this end she suggests it is challenging to analyze in substantive ways the "inclusionary and exclusionary propensities of religion and spirituality" ([25], p. 251). She stresses that the context of Canadian society is shifting with new immigrants arriving from all parts of the world increasing religious diversity (Islam, Hinduism, Sikhism, and Buddhism), in a country that is considered to be a multi-religious society $[13,25]$. Demographic data provides further evidence of "religious vitality" in Canadian society [13]. The ripple effect is "religious complexity" as religious diversity intertwines with Canada's history of secularism, colonialism, current day pluralism, and broader societal trends towards emergent spiritualties beyond the typical organized religions [13]. Therefore, if we believe that nursing practice is relational, we are challenged to "draw upon religion and theology from multiple faith traditions in nursing and healthcare ethics" to better meet the needs of patients and families ([13], p. E3). From a broader social and political perspective questions arise: How does religion, spirituality, and faith intersect with broader public discourse: immigration policy, cultural safety, ethnicity, racism, power, oppression, gender, historical trauma? What theoretical and philosophical approaches might we enlist in our teaching and curriculum planning to support 'difficult, complex, and often tension filled conversations' with students, colleagues, patients and families?

As nurse educators it strikes us that (re) engaging with spirituality requires moving beyond secularism, worry over defining spirituality, and/or the practice of subsuming religion and spirituality as dimensions of culture [24]. Rather, we are looking for a means to illuminate the intersectional nature of religion, spirituality, culture, and ethnicity [24], and return the dialogue to its original "difficulty". What philosophical approaches might we take to ground our learning-teaching practices to best support students in developing the moral sensibilities and knowledge competencies to enter into the "difficult" in respectful and meaningful ways? Similar to contemporary Canadian society, 
our student community echoes religious, spiritual, ethnic and cultural diversity. Reimer Kirkham and colleagues [24] emphasize the need for "safe spaces" in order for nurses to explore diversity, difference and uncertainty, most importantly dialogue is essential. However, dialogue needs to be open to be meaningful. Nurses need the space to critically explore, question, and voice their inner beliefs and values, test their assumptions and perceptions in light of the patients and families they meet in their practice. They require particular characteristics including: a "posture of learning" and "willingness to connect, and a level of comfort with things spiritual" ([24], p. 156). It means accepting a certain level of risk: practitioners need to be prepared to confront their own conflicting beliefs and agendas (social position) [24]. This calls for a commitment to developing an understanding of the intertwining nature of: critical self-awareness, professional boundaries, practice context and organization/institutional social and ruling structures (biomedical technology, workloads, secular culture) [24]. At the interpersonal level it means developing the capacity to connect with the "other"; find common ground, particularly in the face of "differences in religious affiliation, language, and cultural identity" ([24], p. 160).

Our belief is that "safe space" is essential for inner development, critical self-awareness, and the honing of relational consciousness. Relational consciousness "is the action of being mindfully aware of the relational complexities that are at play in a situation", directing our attention to "“relational transactions" within and among people and contexts", so we might act responsively, intentionally, and effectively ([9], p. 5). The first weeks of the fall semester are focused on identity formation. Relational inquiry $[2,9]$ creates the scaffolding for our curriculum and supports our learning-teaching practice. It is a means for practitioners to take seriously "difference", by viewing difference as a living relational space of possibilities and positive growth [9], and put into play particular ontological capacities that foster their ability to connect and relate human being-to-human being. What follows is a discussion of relational inquiry as it pertains to our journey of "attending the spirit" with first year nursing students. Including a discussion on how we have enlisted particular aspects of relation inquiry (e.g., five Cs—capacities) as a means to create "safe space" [9].

\section{Attending the Spirit-Evolving Meanings}

Pat and I (Michelle) have spent many hours over the last three years in conversation, writing, and in the everyday lived practice of relational inquiry. We have thought carefully about how we understand "attending to spirit" and we have reflected on the changes that we have seen over the last 30 years of practice, and considered the dynamic changes in the world at large and in our own lives and the lives that students, patients and families have shared with us. We have noticed a change in how spirituality is understood by our students in their everyday life. It has been a gradual shift; spirituality was once closely associated to church and religion. While today's students seem to perceive their spiritual journey as a search for hope, peace, and authenticity, a search for meaning and purpose and an innate need to be kind, caring/compassionate people [26,27]. Thus, as we have been practicing relational inquiry, we have found Hartrick Doane and Varcoe's explanation of spirituality and caring for families useful when applied to caring "with and for" students:

A spiritual lens makes us curious about the loyalties that are at the center of their lives and in what they are putting their trust- their faith. It raises the question: What leaps of faith are being taken? And what is hoped for in taking those leaps of faith? At the same time it sparks questions about how as nurses we might attend to spirit-how we might nurture the spirit-power ([2], p. 81).

Their explanation does not attempt to define, but rather it remains in the ongoing living space of possibilities. Perhaps that is what makes spirituality so difficult? The fact that we cannot nail it down. It calls us to be "still" in the mystery of it, "to struggle with", it reminds us that perhaps what we are experiencing is as Hartrick Doane and Varcoe suggest something more then interpretation. Something to do with life force and faith (what is between and beyond people)- 
Overall understanding family as a spiritual experience highlights that spirituality cannot be distinguished from other aspects of human existence. We are reminded to seek to know what fundamentally matters to families at the deepest levels of their lives. And finally, looking through a spiritual lens motivates us to 'care-fully' pay attention and attend to what is taking place within, between, and beyond people ([2], p. 81).

A reminder that humanity "has a spiritual dimension" and, reasonably, nurses who claim to provide holistic care "must pay attention to this spiritual dimension" so they can offer kind and genuinely compassionate care to their patients during critical moments in their life ([4], p. 103). However, where, when and how do you begin to explore the religious and spiritual aspect of caring with students? How do we prepare students for the complexity of relational nursing practice-so they might be able to reach out responsively to a mom who has sat in the hallway of a busy emergency department waiting to hear about the status of her daughter who was brought in nonresponsive from an overdose. Exhausted from working two jobs, she appears withdrawn (her energy wavering), few realize that her past experience with health professionals has left her worried that somehow her being a single mom will impact the care her daughter is receiving, in her uncertainty she is silent. We wonder how nurses can attend to the spirit of their patients/families/colleagues, if they have not discovered how to attend to their own spirit? These are the sorts of questions we have been troubling with and we invite you into our journey of being relational caring practitioners, into the never-lands of understanding, where meaning is always and already elusive and evolving. We have learnt as the philosopher Gadamer suggests, that something happens when we are underway in our search for: understanding, meaning, and purpose [28].

\section{Relational Inquiry-Attending to Spirit}

Hartrick Doane and Varcoe [2] use a phrase in their understanding of the spiritual within relational inquiry and it struck us as being very applicable to our journey with first year nursing students-"attending to spirit". They ask two fundamental questions: "So how might we as nurses' 'attend to and care for spirit'? How might we recognize, honor, and care for the life force of people/families?" ([2], p. 79).

In spite of the ever-growing body of knowledge on spirituality in nursing, spirituality is rarely addressed in academic and clinical education, and for nurses who do contemplate spirituality in their work, they "often experience cognitive dissonance in attempting to integrate spiritual care into science-based nursing practice" ([2], pp. 76-77). For those involved in the teaching and mentoring of nursing students, nurses and health professionals, certain questions persist: what is spirituality, what is spiritual care, how do you learn to provide spiritual care, and how do you teach students spiritual care? $[29,30]$ In nursing literature we found an interwoven tapestry of ideas: spirituality has something to do with meaning making and purpose [2,26,27,31,32]; it is related to values and beliefs; it is subjective verses objective, and related to traits of honesty, love, caring and compassion, wisdom, imagination and creativity [33]. Astin suggests spirituality points to our interiors/our subjective life, having to do with human consciousness "what we experience privately in our subjective awareness" ([26], p. 34). It is a living space wherein we hold tight to our values, letting them guide our way of being in the world, shaping our sense of who we are and where we are from [26]. Spirituality has something to say about why we are here and gives meaning and purpose to our work and our life, our connectedness to each other and to the world we live in. Spirituality holds "aspects of our experience that are not easy to define or talked about, such things as intuition, inspiration, the mysterious, and the mystical" ([26], p. 34). Stern and James draw on the work of philosopher's Martin Buber and James Macmurray further broadening this discussion [30]. They suggest that (i) the essential aspect of spirituality is relationships; and (ii) particular types of "actions" come to play within spiritual relationships, actions that are interwoven and include: (a) awareness-sensing (here-and-now, tuning, flow, and focusing); (b) mystery-sensing (wonder and awe and imagination); (c) value-sensing (delight 
and despair, ultimate goodness and meaning). Relationships in this instance refer to "self", "other", "others" (groups—communities and institutions), and world [30].

What Relational Inquiry [2,9] offers is a means of decontextualizing and recontextualizing our stories and experiences [34]. It is a means of holding tensions creatively to reveal particular aspects of our way of being in the world, drawing from the traditions of hermeneutics and phenomenology, critical theory and post-structuralism. It highlights and supports an interplay between the intrapersonal, interpersonal and contextual domains of the knowing process $[9,34,35]$. Table 1 represents our early understandings of relational inquiry, particularly aspects of what Hartrick Doane and Varcoe note to be "attending to spirit" and relational caring. Aspects that assist nurses to "recognize, honor, and care for the life force of people/families" ([2], p. 79). It is not intended to be a "how too" but represents our early attempts of getting to know this new ontological landscape we have found ourselves in.

Table 1. Attending to spirit.

\begin{tabular}{|c|c|}
\hline Domains & Attending to Spirit \\
\hline $\begin{array}{l}\text { Intrapersonal- reflexivity, } \\
\text { critical self-awareness }\end{array}$ & $\begin{array}{l}\text { Developing self-awareness of where one's beliefs, values, norms, } \\
\text { customs, cultural and spiritual lifescapes (s); personal-socio } \\
\text { historical locations } \\
\text { Re-imaging 'life force' — what lies beyond the physical, } \\
\text { psychological, and social — the strength and life forces that } \\
\text { constitutes, inspires, and shapes our lives. } \\
\text { Attending to spirit-recognizing, honoring, and caring for life } \\
\text { force (self and others); } \\
\text { Re-Considering 'faith'-how we find coherence and give meaning } \\
\text { to the experiences and relations in our lives. } \\
\text { Being Compassionate/Curious/Creative/Inquiring-learning how to } \\
\text { be open and embrace the unknown/uncertain; re-imagine } \\
\text { the unknown; } \\
\text { Conscious Inquiry-learning to examine how we come to } \\
\text { understand our assumptions and beliefs, by questioning how we } \\
\text { privilege certain ideas; what we value or not, what knowledge's } \\
\text { inform our assumptions, values and beliefs; explore how one's } \\
\text { assumptions, values and beliefs shape the way we relate to } \\
\text { others, self, and environment. }\end{array}$ \\
\hline $\begin{array}{l}\text { Interpersonal-meeting } \\
\text { others where they are; } \\
\text { personaland } \\
\text { contextual knowing }\end{array}$ & $\begin{array}{l}\text { Critiquing-power, vision, hope, life force } \\
\text { Appreciating learning as a living process-embracing the } \\
\text { interwoven nature of experiential, theoretical, practice learning } \\
\text { Dialogue as process-involving intentionality, learning to be } \\
\text { present, and how to listen with all one's senses including } \\
\text { glances, touch, voice tone, learning to be open, nonjudgmental } \\
\text { and open to others. }\end{array}$ \\
\hline $\begin{array}{l}\text { Contextual-unique } \\
\text { personal, socio-historical } \\
\text { location-shaping } \\
\text { identity, experience, } \\
\text { interpretations }\end{array}$ & $\begin{array}{l}\text { Recognizing - how people and place shape our understanding of } \\
\text { self, other, world; and our understanding of health, well-being, } \\
\text { suffering, faith, spirit, and life force. Exploring how } \\
\text { socio-political, economic, historical forces shape our identity, } \\
\text { experiences, interpretations of self, other, world. }\end{array}$ \\
\hline
\end{tabular}

Note: * the "domains" are based on Hartrick Doane and Varcoe [9,35], and "attending the spirit" is based on Hartrick Doane and Varcoe's [2] writings of reconciling the spiritual and the scientific, particularly their articulation of "attending the spirit".

\section{A Closer Look into Relational Inquiry-“Attending the Spirit"}

\subsection{The Impetus for Change}

The practice arena students are entering is chaotic, highly technical, culturally diverse, fast paced, with a constantly shifting biomedical knowledge base, followed by a growing emphasis on specialized 
care $[36,37]$. We live in a time of "knowledge abundance" and subsequently it has changed how we proceed in the classroom, our approach is frequently content focused in our attempt to get "it all in" [38]. The pull is incredible, drawing one towards the "'knowing" and "covering the content"" ([37], p. 21), but given the complexity and troubling nature of the practice arena and the increasing diversity of today's student population, this content-driven compulsive pull seems ill-positioned when addressing today's practice realities [37].

While we are focused on content, others-students, graduates, and clinical teachers report today's work place environments are "troubling places" to practice, at the interpersonal level (nurse to nurse, nurse to environment). Many have had experiences with incivility and hostility within the clinical setting, and describe experiences of group think amongst staff that lead a group of practitioners to target a colleague using intimidating and threatening behavior [39]. All are concerned with the efficiency and technological practices that seem to be reducing "what nurses and patients do" to tasks and check-lists within electronic medical record systems, that become the official account of the care interactions between nurses and patients. For example: vitals signs, input and output, medication sheets, and dressings descriptor lists, it is not often that a nurse can chart without the interface of system generated descriptors and/or procedural check-lists [40]. More troubling is how these sorts of approaches shape interpersonal relationships and/or how so called efficiency approaches impact the care being provided to patients [39] and, over time, the health and well-being of practitioners. The impact of incivility and efficiency practices on students and clinical faculty varies but can include self-doubt, shame, and feelings of hopelessness that can lead to physical, emotional and spiritual trauma within the practitioner [41]. We have noted with students that the guilt and burden associated with the fallout of these sorts of events, can impact a student's sense of self and professional identity. For some, a lasting affect that takes the form of moral residue.

At the same time, we are concerned that many students entering university today are not prepared to cope with the demands of undergraduate education, and it becomes increasingly difficult for them if they are also experiencing challenges with stress, anxiety, and/or depression in their lives [42]. Furthermore, many of our students are first generation university students (the only one's in their family to attend university), and they report experiencing a great sense of burden to succeed. As well we notice that many students are juggling jobs and family responsibilities, school is just one aspect of their life, thus they have difficulty getting to-studying, assignments, and clinical preparation. Our learning population is diverse-culturally, economically, socially, spiritually, and generationally. We see many millennial Generation Y students (born after 1980) who are highly technologically skilled and dependent (constantly engaging with their cellphones, text messaging in class) [43]. At the same time, students report finding it uncomfortable and difficult to engage in meaningful dialogues in the classroom, noting they are "just not use to communicating this way". However, they are comfortable questioning and challenging authority but have difficulty receiving constructive feed-back [43]. Additionally, this generation prefers to learn in "snap shots", they are not as likely to come prepared to class, and have difficulty taking lecture notes and keeping up with their readings; they report being uncomfortable with interpretive and analytic writing.

\subsection{Our Aims}

In essence, we were seeking a particular type of change, one that is reflective of an "ontological turn" that would "intentionally orient the educative process ontologically and explicitly put epistemology at the service of ontology" ([37], p. 21). Our aim was to imagine an approach to learning-teaching that could support the students to develop the knowledge, skills and moral sensibilities to practice within today's complex and sometimes troubling healthcare milieu. What we discovered is this sort of approach shifts the relationship between epistemology and ontology by shedding light on the "manner in which nursing knowledge and action intersect with subjectivity and context" ([37], p. 21). 
Plainly speaking, it turned our world upside down and inside out, instead of focusing on the epistemological roots of our work (knowledge of abundance), where the subject under study is the content students need to learn (theory, anatomy, pathophysiology, psychology, and so forth), our focus began in the reverse direction, from the ontological shoreline, where the subject of learning-teaching is the student as a developing human being; as a developing nurse. As Hartrick Doane and Brown explain "The ontology of the student (i.e., his or her way of being a nurse) becomes the primary focus" ([37], p. 22). It is reminiscent of Dewey's challenge that teaching is about the formation of the learner and therefore calls attention to the "actual life-experience" of the student ([20], p. 89). To fully appreciate what is meant by "living our knowledge" [44], we are called (learner-teacher-practitioners) to thoughtfully look inward and in doing so it brings into question not only our beliefs and values about learning and practice, but our habitus, and how we understand "knowing" and who is the knower [20]. It means re-considering how the structures of our academic settings, permeate what we do and how we know what to do as learner-teachers [20]. It draws into focus the "intimate and necessary relation between the processes of actual experience and education" ([20], p. 20). It means relinquishing the educative authority associated with content-based and method-based teaching in order to "align the process of nursing education with the process of nursing practice" ([44], p. 99). In some ways it is a relief to surrender to "living our knowledge", how often do we feel like we are pouring content into our students as if filling a glass with water and watching it overflow? How many of our course outlines read like a grocery list of content? Brown and Hartrick Doane skillfully utilize Williams Yeats poetry to explain what could lie beyond "content-based" education:

To approach teaching in a way that lights fires is quite different than undertaking the job of filling buckets. To light fires, we believe that learning/teaching must be structured not according to substantive content and/or educational methods but in accordance with the ever changing process of nursing practice ([44], p. 99).

We found ourselves in what Mezirow and Taylor describe as a "disorienting dilemma" ([45], p. 19) and at the same time immersed in the energy that comes from anticipating the unknown, that is characteristically part of each year's journey-

Travelers prepare more or less carefully for the adventures they hope to have, but the itineraries, maps, and plans do not in themselves create the voyage. The journey is an experience, lived as just the thing it turns out to be: moment-by-moment, day-by-day, month-by-month ([46], p. 11).

We discovered that this sort of approach requires an appreciation for the journey lived. It calls into question what we think we know, and how we translate what we know in our doing of learning-teaching practice. At the same time, it challenges our sense of certainty, we become like our students on the first day of class, looking for some sense of security, something solid and tangible to hold on too that can anchor us.

Pragmatism was the metaphorical "rope to the barn door", that we held on tightly too as we navigated our way in the storm that blew in, like a northern squall when we strategically choose to switch epistemological directions. Relational inquiry arises from a pragmatic understanding of knowledge development rooted in the work of philosophers-William James, John Dewey, Richard Rorty, and Barbara Thayer-Bacon [2,9,44]. Holding tight to the belief of living knowledge-as the philosopher Hadot suggested we recognize that knowledge can be viewed theoretically (as abstracted and devoid of life), but it is so much more [47]. Pragmatism broadens how knowledge is understood. It helps us look beyond, towards a different philosophical point in the horizon where knowledge arises from the very "art of living" ([47], p. 28), an understanding which premises knowledge to be "'socially constructed by embedded, embodied people" ([2], p. 10). Thus knowledge, as knowing and unknowing - is experienced, practiced and lived between people [47]. From this perspective, expert truth is fragile and at it's best is a moving target, something you glimpse from a peripheral view with 
great skepticism and scrutiny. In a manner of speaking pragmatism weaves the world in all its complex dimensionality back together again — knowledge, theory and practice are interwoven, as theory is understood to arise from experience and practice $[2,9,44,48]$.

From this emerging vantage, there exists multiple truths and interpretations $[2,9,44]$; knowing is a relational process that calls for wholeness of mind, body and spirit. This suggests we can never really separate ourselves from our experiences, as the Cartesian perspective would have us do. As practitioners, this comes with such a sense of relief. You can breath again-because it opens a space for our sensual, imaginative, interpretive, and analytical existence-we are free to practice the living art and science of relational caring. It holds tight the notion that the knower is always and already central to the knowing process $[2,9,44]$. You do not have to separate out how you know a "heart attack" rather; you have to embrace the complexity of it. How one's theoretical understanding of "heart attack" (anatomy and physiology, and pathophysiology) comes to play in the moments of being with a person having a heart attack, and one's many experiences of having been with patients in that moment all merge in the present experience of being with the patient in front of you who is now in the process of knowing-a heart attack. Furthermore, you become aware of the shifting life force of the person in front of you - their eyes bright with fear and pain. At the same time, this new ontological direction does create some angst as learner-teachers, because it means we need to re-consider how we are approaching learning-teaching from a living knowledge perspective, what do we foreground, what do we backdrop and how do we merge the two with/for our learners, how do you teach them about "life force" is it even in their textbook? Our hope, as "good learner-teachers" is that students can experience as learners/practitioners the join that exists between knowing experientially and theoretically, that we experience what lies beyond the physical, logical, rationale, interpreted, to "illuminate the soulful 'spirit' or life force of people/families" ([2], p. 78).

Our experience has taught us that like the rope leading to the barn door in the midst of a winter squall, certain aspects of the how of our teaching life remain constant: substantive content, evaluation strategies, classroom management astride educative methods and teaching strategies, still essential to all that we do. However, in what ways do the essentials shift when the centre of our learning-teaching lives is students' as "learning people" ([44], p. 106)? "In order to ensure that nursing and the people involved in learning "take center stage", content and methods need to become useful tools and resources as opposed to the substance of nursing education" ([44], p. 106).

\section{Critical Relationships-Letting Learners "Take Center Stage"}

The first nursing theory course students take in the fall introduces them to what students frequently considered abstract and soft—core theoretical nursing concepts (e.g., care, compassion, spirituality, self identity). Drawing on Dewey's [20] notion that all experience is educative and/or potentially mis-educative, we purposefully enlisted the students' current experience of being "disorientated" and "unsure" as they entered this new space of transition in their lives [36]. Thus the space of transitioning became a space for exploring in meaningful ways foundational nursing concepts like caring and compassion, self-concept and identity, spirituality, and culture [36]. We aimed to develop a learning experience, whereby nursing's core theoretical concepts could be lived by students. To this end, we created an narrative-learning-experience utilizing relational inquiry as the scaffolding for the fall semester of their first undergraduate year [36].

In a nutshell, we carefully created interconnected learning spaces, in the classroom, the laboratory setting, and on-line learning environment. Thus, instead of posting power points that typically accompany chapter content about caring and compassion we posted invitations on the on-line course web page. Our course outlines-once chucked full of chapter "subject" content, now were full of experientially and narrative-based learning opportunities for getting to know self and colleagues. Yes, you could still spot content, but it was situated differently. Once learners had a chance to gain the capacities for intentional meaning making through memory, recollection, reflection of their individual life experiences, they began to glimpse for themselves relational caring practice with one another as 
they began the "being, doing, knowing" of nursing practice. Their experience of caring for one another throughout the initial narrative-based experiences, helped them to find the bits and pieces of theory that resonated with them, and subsequently helped expand what they learned in "doing and being" of caring for and honoring one another. They drew on theory to broaden in meaningful ways their expanding ideas about self, caring, compassion, spirituality, moral agency and culture.

Story-telling became a means for creating conductivity between learning sites (classroom, laboratory, on-line). Learning how to create and tell stories with purpose was a means for them to explore practices based in self-awareness, recollection and memory making, listening and responding, imagination and creativity. Furthermore, we thought about the many different ways story could be used, including the: written, oral, and picture forms. We decided to use all three approaches: "written" we created space on-line for students in pairs to journal together after and in-between classes; "oral" we created space for sharing circles in the classroom and laboratory settings where students were given time to dialogue together about important aspects of what they were learning and/or share their emerging stories about "self and other", "care and compassion", "spirituality", and so forth. We used "picture form", when students created images of their faces (the outside- the person they showed the world, the inside - their inner self-values, beliefs, sacredly held stories of their lives). As McLean and Thorne suggest, "stories are constructed to make sense of experiences that disrupt individuals' assumptions about their place in the world and their relations with others" ([49], p. 111). We held to the belief that storytelling is an innate aspect of being human and that often the stories we tell have something to do with who we are as human beings [50]. Richard Wagamese proposes that the stores we create often hold the people and places of our life-that shape us [51]. He reflects that stories are important to who we are as human being; we glean from his writing that there is something deeply soulful about the stories we hold to be important in our life:

They are about the people, events and circumstances that have shaped the man I've become at fifty-four. They are about the magic I've found in being a member of this human family. Kin. A part of the one story, the one song we all create together ([51], p. 5).

When we utilize story-telling in the classroom with students, purposefully and spend the time to nurture their capacity to tell a story, as learners we all grow to appreciate that storytelling is

for another just as much as it is for oneself. In the reciprocity that is storytelling, the teller offers herself as guide to the other's self-formation. The other's receipt of that guidance not only recognizes but values the teller. The moral genius of storytelling is that each, teller and listener, enters the space of the story for the other ([52], p. 18).

Students quickly recognize that stories need to be handled with care, how they listen to a story is just as important as how they tell a story. They quickly recognize that stories reflect real people and thus require care and respect. They grow to understand that their story is part of a bigger story, as Richard notes "part of one story, the one song we all create together" the reciprocal nature of storytelling, particular during periods of transitioning can be powerful, and thus require nurturing.

\section{Meaningful Felt Invitation-“'Connecting the Life Each Learner Lived Fully Outside of School with the Life We Offer in the Classroom"}

Our journey began with our own recalling and talking about what we found meaningful in our learning-teaching practice, and about how we understood relational caring practice in our everyday lives. We explored our own journeys to being and becoming nurses, the many points of transition and challenges we have traversed throughout our years of nursing practice. We talked about times of uncertainty and how we found our way through and came to see the importance of being in relation with "others". We considered the implication of context within our practice and the importance of "person and place" (past and present) during transitioning. We recalled that in our own early nursing education, little emphasis was placed on understanding "self" and "other". Neither of us could recall 
ever been asked about our life outside school before nursing, and yet our life outside nursing was key to our coming to nursing. We elicited our individual memories of when we first understood caring in our lives, and we considered how important our life experiences had been to who we were as human beings, and as nurses. In our conversations the question that continued to arise was-What if we invited the lives of our students into the classroom, how would we do that, what would that look like, what were we asking of the students, of ourselves? We believed that in order for students to fully appreciate the transition they were entering as they moved towards the yet unknown-nursing journey, it was imperative that they understood where they had come from, the people and places that shaped who they were, including their beliefs and values that shaped in tangible and intangible ways how they were in the world. Our goal to "connect the life each child lived fully and completely outside the school with the life we were offering inside its doors" ([46], p. 29).

\subsection{Invitations}

Prior to the first day of class we invited the students to explore the course web site, letting them know they had been randomly assigned a learning partner whom they would be working with throughout their first nursing theory course. We then created a writing space for each pair of students, that only they would have access to. Each week after their nursing theory class, students were provided a space to write, and encouraged to share their experiences, the work they had done together in class, reflecting on what they had learnt about being a student, or concerns about learning that had arisen for them during the week. From a spiritual perspective it gave the students a space to consider in the moment "what ultimate concerns shaped their lives?" [2]—it provided them the space to consider the daily events and situations that they were engrossed in relative to the larger life situations that permeating their experience of being a student. In our time with students we listened carefully to what was occurring for them, and beyond them.

Stepping into the classroom for the first time-we "invited" students in before they stepped physically into the classroom believing that getting ready to enter was just as an important a time as the actual arriving - a good part of a journey is the anticipation and preparation of it. Students came prepared to "find" their partners, they reported that they had contacted one another through their on-line journal site, giving descriptions, using text messaging and so forth, some deciding to meet on the "way in" in the hall or at the coffee shop where they could walk over together.

Travelers prepare more or less carefully for the adventures they hope to have, but the itineraries, maps, and plans do not in themselves create the voyage. The journey is an experience, lived as just the thing it turns out to be: moment-by-moment, day-by-day, month-by-month ([46], p.11).

They were already sharing bits and pieces of their individual stories about "coming to nursing". Standing at the front of the lecture theatre we watched as students entered finding their seats, some having found their partners talking avidly about what was to come, others looking around to see if they could recognize their partner and waving one another down-or checking their phones as they messaged their partner looking up to find them with the arrival of a returning text, it took less then 10 minutes for 200 students to orientate to finding one another. The classroom was a buzz with voices, we found ourselves caught up as we watched and listened to the chaos-letting the energy of that moment vibrate within us as teachers. A living curriculum celebrates the coming together of students and teachers, and calls into action:

Each of us, teacher and child alike, walks through the door bringing experiences and understandings that are ours alone. Yet, each person is also embarking on a journey that he or she will come to share with others. This journey is made anew every year with every class ([46], p. 11).

We waited for stragglers to find their way. We reflected back to them how excited we were for the fall term to begin and the amazing energy they brought into the classroom and how it resonated 
in us as teachers-re-affirming in us our commitment to relational caring practice. We reflected back to them how important we believed this time to be for them individually and for "us" (students and teachers) as we were forming a community together ... a new community of people drawn together by an intention to "be and become" nurses.

We invited them to take a few seconds just to breath, to settle in, to appreciate the moment. We then explored the learning map we had envisioned for their first nursing theory course and how they would be exploring key concepts (self, caring, compassion, spirituality, moral agency, and culture), but more importantly how they would be actively recalling, re-considering and creating their own meanings of these concepts in relation to being and becoming nurses. Ultimately gaining a deeper understanding of what it meant to be a relational caring practitioner. Then we opened the space for learning "together" we provided the students with a set a questions that we have found to be useful when students are taking the first steps in their nursing education, the students spend the next hour together discussing the four questions. We invited them to consider what it means to listen with intention and attention to a person's story and asked them over the next two days to write their partner's story and share it with their partner by posting it in their private on-line journaling space, where they can further respond to one another. Questions: Where's home (your community, your life prior to nursing school, the landscape of your life - the important people and places of your life)? What shaped your decision to come into nursing? What are your early hopes/goals as you begin your nursing education? Where do you see your self at the end of your nursing education?

The exercise at first appears simple, but in actuality to listen and receive a story comes as students discover that stories told and received come with a sense of "responsibility and obligation" for teller and listener [34,36]. Students shared in class how this sort of "story-telling" was something more and they recognized that you have to listen carefully. You don't want to miss anything. We heard multiple times that they felt the need to "get it right" and instinctively they believed that they had to be careful with one another's stories-a person's story is sacred. We had made it clear in the course outline and in the work activity descriptions that their on-line journal space was a private space for student reflections and story-telling and that only they would have access, and we asked students to talk about what they expected from one another in relation to "private" and "holding another's story in confidence". We kept to our promise with students, we never looked into their on line journaling space, other then the system alerting us to the number of times students entered journal notes (the numerical statistics) we held sacred and trusted they would meet their responsibilities and obligations as learners to one another, and participate to the best of their abilities in their collective learning, and for the most part students did just that. To provide you with a glimpse into our world with students, in the cherishing of stories, a student gracious permitted us to share the following reflection:

As a mature student returning after 20 years I did not know what to expect at all and I can say how blessed I feel that I came upon this process... It has been a difficult road to get here and to start it off by really looking at who I am as I embark on this journey was very powerful. Also bonding with my partner who now feels like family was such a gift! [53].

\subsection{Connecting On-Line to Life in the Classroom}

Each week we checked in with students as to how the on-line shared writing space was working for them, students reported that it was an excellent space to quickly share insights into what they were learning. It brought to mind that from a spiritual perspective their engagement and commitment of shared stories and critical reflections brought them into a space of attending to spirit without us actually defining spirituality with them. Hartrick Doane and Varcoe suggest an aspect of "attending to spirit" is to learn to inquire into the concerns shaping people's lives by learning to "pay attention to how people/families are moving into and through life, at how they are 'presencing' themselves within their world, and what commitments are guiding their life choices and decisions" ([2], p. 81). As students discovered that they shared many of the same concerns and worries they gained a sense of "belonging" - their collective sense of disorientation became a means to connectedness. Students 
reflected they were learning to take the time to listen and letting their partners stories sink in. When they were in class we observed students encouraging one another to talk or explain a point they had made. We witnessed acts of great kindness, as students began to question their own understandings of a concept-sometimes struggling with the language of a theory, their colleagues would come to the rescue if they knew the words, or gently suggest "did you mean" or "could it be this ... ", we recognized in those moments that students were living "presencing" with one another and responding verses reacting, they were thinking about what the other said (or could not say), and were supporting one another's learning journeys.

\section{The Back and Forth Momentum of-Creating Safe Spaces}

\subsection{Creating Safe Space-Enlisting Compassion}

In our teaching-learning practice, creating safe space stems from our use of the five Cs (capacities) of relational inquiry. To support students as they contemplate the complexities of being intentional and thoughtful in their conversations about identity formation in relation to issues of religion and spirituality, we turn towards relational inquiry, narrowing in on the ontological capacities of relational inquiry [9]. When we use the term capacity, we are not referring to behavioral skills, rather, a natural ability to "let go" of oneself [54]. With the learner in mind, we believe that spaces safe for learning are spaces where students are able to let lose of oneself, while being able to observe the "other" [54]. For example often students when taught therapeutic communication, become so focused on "doing it right", their mind is full of things like 'open and closed' ended sentences (self conscious practice), so full that their natural ability to be in a caring-human-relation is suspended by behavioral performance [54]. Approaching human relating as a caring process enfolds intent, knowing and unknowing, curiosity, being compassionate, and committed [9]. Relational caring practice "requires an appreciation of people's connectedness, the development of relational awareness and an interest in the movement of relationship" ([54], p. 524). Thus, we begin our conversation about safe spaces, by exploring more closely what we mean by compassion and suffering from a relational space of connecting as human being-to-human being. We believe that compassion is at the center of safe spaces in learning communities, where human relations are central, and can be viewed from an ontological perspective as a interwoven complexity of compassionate capacities (e.g., the five Cs of relational inquiry).

\section{2. (Re) Discovering and Uncovering Compassion}

The foundation of relational inquiry is "being compassionate" [9]. Compassion is the most fundamental capacity nurses require to be relational practitioners [9]. While compassion may seem on the surface to be simply a human emotion, to act compassionately as a nurse requires conscious intent and a particular way of being [9]. Compassion means "to share suffering"; thus to be compassionate calls us "to relate human being to human being-to share something of ourselves and of what it is to be human" ([9], p. 103). One of our very early discussions with students is how they understand compassion and suffering - and the idea of sharing "something of ourselves and relating". Paraphrasing Hartrick [54] when nurses are able to be in-compassionate-relations, it is their ability to trust in themselves as a compassionate person that nurtures their connection with others and supports their ability to attend more responsively and effectively to the other. It is foundational to the conversation/narrative work that is to follow, as students begin to explore identity, and locate oneself in the weave of human history, ancestry, diversity and so forth [9]. Hartrick Doane and Varcoe's [9] employ John Caputo's [55] description of suffering in their discussion of compassion. Discovering the meaning and interrelated nature of compassion and suffering is useful when attempting to create "safe spaces" where students are being invited to create and share life stories; explore identity. Compassion as an ontological capacity provides students a space and way of being, as they begin to recall and re-imagine meaningful moments in their life, that translate into action (or not); inform who they are as developing human beings. Philosophically, suffering is something which: "humbles us, brings 
us up short, stops us in our tracks, something surpassing which inspires a mix of fear and awe and admiration, something which both strikes us down and draws us near" ([55], p. 275).

Caputo's description triggers them to recall how some events in their life caused them to step back and take notice; even creating "inner conflict", frequently accompanied by a cascading kaleidoscope of feelings: stress, worry, sadness, anger, excitement, apprehension, or joy. We ask them to consider, whether moments that "stop us in our tracks" can change a person (sometimes in small ways, other times profoundly). It's an opportunity to learn from their life experience; to work through why they continue to hold the memories of particular people, places and moments in time. We are intentionally drawing students into the living world, helping them discover that being compassionate is an experience lived between people $[9,56,57]$. This requires adeptness for imagination. Part of our work, is to uncover/recover (for many students) imagination, it is an aspect of creative inquiry, which embraces specific practices: critiquing location and power; re-envisioning truth as an active process of interpretation [44], and is required for the ontological capacity—curiosity (which we will discuss further on) [9,56,57]. Hartrick [57] refer to Policastro and Gardner's [58] description of imagination as a form of "playful analogical thinking" where past experiences are recalled and combined in new and emerging ways, creating new patterns of meaning. Imagination is needed when students are exploring fundamental nursing concepts (compassion) from a lived perspective, attempting to sort out the meaning of being compassionate in everyday personal and professional human-to-human relations.

What we hope students discover, as Hartrick Daone and Varcoe emphasize is compassion is more than emotion, more than "doing". It is "about being in solidarity and doing with another" ([9], p. 107); demands a synergy of reason, emotion, and feeling, calling us to act [9]. What distinguishes compassionate action is how we relate! To help students gain a better understanding of this, we have adapted Hartrick Doane and Varcoe's "Compassion Requires Us to Be in the Difficulty" questions ([9], p. 107). We use their questions in relation to where the students are in their learning (first year, fall term, learning fundamental nursing concepts and communication skills, no clinical experience). In the first few days of school, they enter class not knowing one another, trying to absorb course outlines, volumes of readings, sitting in lecture theatres, not yet comfortable with talking in front of "so many" new people. To create a sense of "community and solidarity" in this space of strangeness, we partner the students and using small group dialogue to harness their experience of transitioning. In the course outline it indicates the topics for this class are self-concept, identity formation and compassion. Staying in the moment with them, we asked them to think about compassion as they reflect on what they experienced/felt when they first meet their on-line learning partner and completed the exercise of creating and sharing their "life story" (who they are, where they come from and so forth). We asked them to consider how they were enacting compassion towards self and other (colleagues) in this moment. They were to consider the following questions based on their ability to recall and re-imagine previous life experiences in relation to their emerging experience of getting to know one another through their sharing of "life story":

How have you learned to "do" compassion? What does it mean to be compassionate?

Do you feel responsible to honor the life stories you have just shared?

Do you have the capacity to be with people and situations as they are unfolding at this particular moment in time?

Something to consider: While it is fine to say that compassion requires us to embrace uncertainty. It can be difficult when we find ourselves in new situations, not knowing anyone, feeling uncomfortable, and/or at odds with our colleagues, who may be thinking, saying, or feeling something completely different (e.g., how we are reading a situation can be different then our colleagues are interpreting the situation, or may be our beliefs and values are at odds with our colleagues). Yet, we still want to understand more fully the other person's position and experience, we want to be compassionate. How do we 
reconcile these competing elements within ourselves, recognizing-our collegial learner obligation to respectfully be with people in their experiences, balancing these concerns with our own needs and agendas; yet wanting to respond in some helpful way? (Questions adapted from Hartrick Doane and Varcoe, [9], p. 107)

Many students are not yet use to talking with intention and attention to specific ideas/ideals in front of others, particularly people they do not know; they rightly recognize the need for safety. Because most people perceive compassion to be a simple human emotion, it is a natural beginning dialogue concept for students; they are able to talk about it with some sense of security, particularly if they are drawing on current experiences. But, they learn from letting go "defining compassion", that the meaning of compassion stemming from lived experience is complex, and has to do with being compassionate. Suddenly, the experience of sharing their life story in the first few minutes of class, takes on new meaning, and consideration, in light of what it means to be compassionate. Compassion from a nursing perspective, they quickly discover holds certain obligations and moral sensibilities, it calls for authenticity, integrity, respect, and dignity. Thus, in partners and then collectively, learners begin to create what safe space means, and how they imagine being compassionate.

Unbeknownst to them, students are taking the ontological turn with us, rather then route memorization of content (definitions of compassion), they are acquiring the habit of drawing from the knowing inherent in lived experiences of compassion to create new understandings. Moreover, putting these emerging understandings into action. For example: being genuine with one another and respectful in how they use their voice to question and how they learn to listen with all of their senses (e.g., physiological, emotive, spirit). We explore with students how they hope to relate compassionately with one another throughout the lifespan of the course, and their undergraduate education and into professional practice. This is the beginning of creating safe space. This sort of practice calls for interpretation, and the nourishing of imagination and curiosity. It is human nature to want to define, and nail down what is known, but nursing is a human practice of relating and knowing is dynamic and contextual, and non-static. Thus, with each first year nursing class comes new nuances of how compassion is taken up; the creation of safe spaces transpires. What we can say about compassion and safe spaces is that in simple learning moments such as these, students discover that compassion is something they need to cultivate for the preservation and well being of self and other. Compassion is not merely a human emotion, and a need to "do" [9]. As students make this discovery, we take the next step and introduce students to the five Cs of relational inquiry [9], that further shore up their/our understanding of safe spaces for learning and practicing together.

\subsection{Creating Safe Space-Enlisting the Five Cs of Relational Inquiry}

The five Cs (capacities) of relational inquiry include: being compassionate, curious, committed, competent, and corresponding [9]. In our practice, we view the five Cs within the context of the three interwoven relational practice domains (see Table 1 "Attending the Spirit"): intrapersonal (reflexivity, critical self awareness), interpersonal (meeting others where they are through listening and presence) and contextual (social-historical location) [9]. In the context of this article, we will discuss three of the five Cs (capacities) as the foundation for creating safe spaces: being compassionate (specifically compassion for self), curiosity, and commitment (difference as a site for practicing commitment).

\subsection{Being Compassionate—Compassion for Self (Intra Personal)}

We move from uncovering the meaning of compassion, to an exploration of: compassion for self. This requires consciously taking note of one's experience, and scrutinizing the knowing and understanding that comes from compassionate inquiry at the intrapersonal level [9]. The aim is to bring a more thoughtful self into our human encounters and practice by making intentional choices on "how to focus, respond, and use the capacities we have at our disposal" ([9], p. 113). It draws our attention to our bodily sensations, emotions and thoughts as we respond in the moment [9]. It calls us to think about what is shaping those responses, what is drawing our attention [9]. It means 
taking a second look at our actions and reactions, we become more careful [9]. It lets us glimpse our "contradictive self" [9]. It provides a space to reconsider the contextual values we have absorbed (normalized); how we often find ourselves working between competing values tugging and pulling us in all directions. Ultimately, learning to attend to one's experiences is a "very direct way of caring for our own well-being" ([9], p. 113). (Note: alongside the fall foundational nursing theory class students are studying therapeutic communication in their laboratory classes).

Hartrick and Doane emphasize the simplest means to draw compassion towards one's self is retrospectively [9]. We ask students to think back over their experience of making the decision to apply to nursing and come to university. To re-imagine when they made that decision, step back into that moment in time and give way to memory. For some students they recall the day they received their acceptance letter, others recall telling their parents they wanted to go to university, or telling their significant other they wanted to change careers and go back to school, quit their jobs. We have adapted Hartrick Doane and Varcoe's "Looking through the Cracks" ([9], p. 114) questions, the questions act as the invisible thread connecting past, present, and future, drawing on one's imagination to re-image that moment in time. We encourage them to use these questions anytime they encounter "unknown and/or uncertainty", make it part of their relational caring practice:

What are you felling (unsure, confident, confused, not knowing, etc.)?

Of what bodily sensations are you aware?

What are you thinking to yourself?

Consider your aspirations and concerns, how they are shaping the way in which you relate within the situation, and what it tells you about your self.

Identifying what is significant about your experiences in that moment of time, identify any particular values or obligations shaping how you are experiencing the situation.

Looking for any "windows" or "cracks" you might look through to learn more about your self, and/or care for your self.

Explore different ways in which you might make sense of your concerns/worries. (Questions adapted from Hartrick Doane and Varcoe, [9], p. 114)

Because this activity is occurring in the first weeks of their undergraduate education, the students are in transition. They find they can "dig in" to these questions. They have current and emerging memories to anchor them. The often turn the "what are you thinking", into "what was I thinking when I made the decision to come into nursing?" The most common feeling is being overwhelmed. They have yet to learn "balance"; everything is coming at them all at once. Their first experience of writing university tests is occurring in multiple classes, writing their first academic papers, they are energized yet, apprehensive. As we watch and listen, we are drawn to the momentum of human formation. Students, as they harness imagination move between recalling the moment of making the decision and the present: struggling with balance, the emotive and physical responses of anticipation, doubt, and excitement. In these classes we purposefully talk to the students about the students services that are available to them (self care). For example, what does the student learning center offer, the health center, chaplain's office, and library services?

\subsection{Curiosity (Interpersonal)}

Curiosity is the capacity to work between "knowing and unknowing" [9]. From a relational perspective, being curious is an attitude [9]. It means being interested, inquisitive and open to the unknown [9], an essential aspect of safe spaces for learning communities. It means that everything can be called into question-"your knowledge, values, thoughts, emotions, actions, inaction, habits, 
inconsistencies, personhood, the truths governing the clinical context in which you work, and so forth" ([9], p. 115). It requires that learners develop new habits: envisioning [not] knowing as a pathway to becoming knowledgeable, learning to scrutinize with a skeptic eye theory (conceptual frameworks and models) and embrace not knowing as potential space for learning, connecting, and human relating [9]. It requires authenticity, genuineness/generosity, respect and integrity (all aspects of being compassionate). The following is an example of questions that unfold in class with students, when practicing form a place of authenticity where "everything can be called into question":

Questioning our own understandings (e.g., religion and spirituality). For example: where do these ideas stem from in our own life? What constitutes "religion" and/or "spirituality" in our life? How do we live "religion and spirituality"? Are they the same, different, why? Do we relate any aspects of "religion and spirituality" to our "values and/or beliefs", or our very way of being in the world?

Questioning what we know and do not know about our own religious, spiritual and faith practices; and asking in respectful and thoughtful ways about the religious and spiritual needs of patients/families and/or colleagues. For example: Who is writing about religion, spirituality and faith? Do the writings reflect your own understandings? Do you recognize any aspect of your self and/or your understandings in the text writings? How comfortable are we about talking about religion and spirituality (why or why not)? How do we move forward, if our 'values and beliefs' are different? How do you support a person's religious and spiritual needs if you have no understanding about their practices, how do we ask them to explain?

Questioning the theoretical concepts and frameworks (e.g., spirituality models/frameworks) that inform our practice as a nurse in relation to the context of our practice and individual patient experiences. For example: Do the frameworks relate to how you understand spirituality (or not); why? Do they reflect a particular religious tradition (or is there any mention of religion, or faith within the framework?

Conversations whirl. They are unsure if "faith, spirituality and religion" have a place or role in their emerging nursing identity, or if these aspects of their life are something they need to consciously create boundaries around, a separation between private and public life. Students explore the context of their lives; how in everyday relations some aspects of their lives are open, and other aspects perhaps "not" and why not, when and where it is appropriate to share? Conversations arise around personal and collective "assumptions, beliefs and understandings", and how and where our assumptions, beliefs and values arise, at the personal and professional level. They learn from one another how to talk about what they perceive as uncomfortable or difficult, and what "uncomfortable" means to them. They wondered if the "(un) comfortableness" comes from the norms they learned within their family unit, and how social norms function in creating order in community life and/or more broadly society. However, as teachers we notice that the discomfort fades as students become more adept to the "playful use of analogical thinking" (imagination), as they develop the ability to fully engage authentically from a place of the heart, harnessing curiosity.

\subsection{Difference as a Site for Practicing Commitment (Contextual)}

Being committed means to "actively and consciously identify the values and concerns that orient your work as a nurse and continually monitor how your actions are aligning with those commitments" ([9], p. 118). From a relational perspective, commitment is a quality of "investment of oneself in a conscious course of action" ([9], p. 118). In relational inquiry the meaning of difference stems from an antiracist perspective that suggests nurses need to develop the capacity to actively and reflexively scrutinize themselves in light of differences they encounter [9] in the classroom with fellow colleagues (the classroom is their first practice experience, learning to care for self and others). Often 
difference is thought of as "difficult" what Hartrick Doane and Varcoe call "hard spots" [9]. However, they suggest difference is an inherent aspect of any nursing situation, or human encounter-as human beings we have aspects of ourselves that make us different from one another (backgrounds, socio-economic status, family, physiological status) [9]. Thus, learning to appreciate difference as a space of learning, (again embracing knowing and unknowing), means that learning to work across 'differences' is an innate aspect of relational caring practice [9]. It becomes a means for practitioners to become more responsive and effective in nursing practice [9]. Our goal as teachers is to provide space for students to appreciate the powerfulness of difference in everyday life, as Hartrick Daone and Varcoe [9] suggest:

Difference offers a window into ourselves; it is where we bump up against ourselves most strongly and can see our own views, assumptions, values, and habits of mind and action at play. Moreover, it is where we find out what matters to us, what we have trouble tolerating, and to what we are committed and not committed ([9], p. 121).

Thus, we encourage students to embrace difference as an opportunity for growth and development. The following questions we have adapted as a means for students to embrace religious and spiritual difference (Based on Hartrick Doane and Varcoe's "Exploring Your Nursing Commitments", [9], p. 123):

What is the primary concern in this conversation, as (you and I) talk about religion and spirituality?

What are the important factors to consider in identifying "concerns and commitments"?

What is challenging for (you/I) in this situation? What surprises you?

What is it like to focus on illuminating the differences between (you/I) rather then working to find areas of agreement?

What similarities and differences did (you/I) experience? What factors influenced those differences?

What understandings of religion and spirituality can (you/I) identify in one another's thinking, what understandings of religion and spirituality can (you/I) identify?

What different commitments do (you/I) hold in contrast to the other person?

As colleagues what do we (you/I) find particularly challenging about the differences between (you/I)? (Questions adapted from Hartrick and Varcoe, [9], p. 123)

We found that as we spent time assisting students to develop relational compassionate capacities, students became comfortable addressing religion and spirituality, and subsequently a wealth of questions arise. In class and on-line students thoughtfully discuss and explore whether spirituality and faith has something to do with what it means to "be human", and if so, wonder how one can compartmentalize their very "way of being"? Furthermore, can one learn to silence particular aspects of their "way of being"? They reflect on the significance of childhood as an important informative time in their growth and development, recalling how it may be a space to learn social norms, including how they come to understand the role of spirituality, faith and religion in their lives. It is inevitable that students discover the meaning of secularism, when they reflect on whether or not they learnt that religion and spirituality belong to the private world of family and home. Given the great variances of life experiences, we explore with students: What do these diverse understandings of spirituality, faith and religion say about us as individuals and as a society? And is it even possible to separate out these aspects of one's self? What are the societal structures that bracket certain aspects of our 
life in relation to spirituality, faith and religion? What is meant by public verses private? We explore unfolding concerns and worries about how one's expression of spiritual, and particularly religious beliefs and practices, that may be at odds with those around them, and may be taken as oppressive, privileged, or even offensive by some. Difficult conversations.

\subsection{Creating Safe Space- "Looking for the Join"}

As teachers and practitioners, we recognize and acknowledge that religious and spiritual differences can run deep, and we have discovered in our practice with students, in order for students to connect across religious and spiritual differences, they need to meet people where they are-looking "for the join" ([2], p. 292). If nursing is a relational practice, then the:

meeting space (the join) in between differences where ambiguity and ambivalence reside is the focus of practice. 'Differences', whether they are differences in values, beliefs, privileges, practices, concerns, or experiences, both challenge and offer us the greatest opportunities to learn about ourselves, learn about others, and learn about contexts ([2], p. 292).

By supporting students to "meet" their colleagues where they are, they discover that "the join" is a space where difference is about learning and human potential. Safe space can be achieved by enlisting the ontological capacities of: being compassionate, curiosity, and re-envisioning difference as a place of commitment. Our role is to help students to image and re-image different approaches of relating and connecting in meaningful ways with one another, learning to be compassionate practitioners that sustain human dignity and integrity in their everyday practice relations. We have found that claiming compassion as the foundation of relational inquiry [9] has made us think more intentionally about "solidarity" and the importance of creating "community" as essential aspects of creating safe spaces for students to be and become nurses.

\section{Evaluation}

The challenge of course is: How do you evaluate what the students have learned through their reflective writing? The evaluation was consistent with our ontological stance, we provided the students with a reading package mid semester, after they had many experiences in the classroom and on-line building their relationships together. The reading package provided them with theorist's interpretations of caring, compassion, dignity, respect, and spirituality, all aspects of their early steps towards a greater understanding of relational caring practice. We invited the students to look back on the on-line writings and their experiences with one another in the classroom, to recall their initial understandings of core nursing concepts: care, compassion, dignity and spirituality and how had their understandings evolved during their time together. Then we asked the students to read the articles written by the theorists and dialogue on-line with their partner exploring what resonated with them from the readings. The question being: How might these philosophical and theoretical tenets expand their understanding of their lived experience during their first weeks of entering the nursing program?

We instructed the students in their papers to only use the resources we had provided in the learning package. We were careful to provide them with resources that were level appropriate (for first year students) and focused on caring, compassion, dignity and spirituality. We advised them to narrow their focus, and chose one aspect of their experience that they wished to understand better, and to expand their understanding through literature. Some students wanted to know more about a particular idea or theorist and explored further, for example some students explored "presence" and turned to Jean Watson's caritas theory [17] to better understand the nature of presence. The papers were five pages in length including references. We spent time in class reviewing how to write a scholarly paper and integrate literature, and write from a first person perspective, we explored how to write about experience in a respectful way (maintaining privacy) by re-storing their stories. We discussed approaches to constructing an introduction and how to use literature to support their thoughts and ideas on spirituality. Each paper was a unique and individual narrative of their learning experience 
and quiet aesthetic in nature. You can easily see the variance between learners and language literacy. We had not anticipated the level to which students can grasp complex and philosophical ideas and connect these ideas to their everyday lives. This sort of approach is time consuming, as you have to give feedback on their writing skills/competences, and their ability to synthesis their learning, but as well you have to provide room for their aesthetic expressions.

It beckons a return to Dewey's philosophy that the educator needs to ground their practice in creating the philosophy of experience for their students by providing them with the conditions necessary to make learning a reality for the learner [20]. You have to provide students the space, time, resources, and distance for them to struggle and experience cognitive dissonance: the suffering that is inherent in deep philosophical learning that arises from experiential learning [20,46]. First year students tell us "it's hard, so much is coming at us all at once, sometimes you don't even know where to look" and they often reflect, "I can read and read and it is not sinking in". What we find however, given time and space, experience and dialogue, they return to class and tell us "I get it now" and when we ask why they tell us about an experience in their life that creating meaning and context to the theory they struggled to understand-learning has become a reality.

\section{Taking the Ontological Turn-"Attending the Spirit"}

Over the last three years, through curriculum renewal and re-thinking the meaning of learning-teaching in our daily practice with learners and through our own reflecting and wondering, our writing, the two of us have taken seriously what it means to take the "ontological turn" to redirect our attention from "content" to the "ontology of the student (his or her own way of being in the world)" ([37], p. 22). When we began this work we could never have imagined the journey we were about to take, nor the changes it would make in us, or how we understood our teaching practice. It has redirected our attention from teaching to learning. It has moved us away from teaching and learning as an individual endeavor to learning as a community. It has brought us to a space that appreciates a more spiritual approach to pedagogy (for lack of better words). A place where we are keenly aware of how we "attend the spirit" of our students, as we purposefully focus and with intention support our students to discover the interconnected nature of their life, the weaving together of intrapersonal knowing (inner worlds); interpersonal knowing (others) and contextual knowing (socio-political, historical, economic). Specifically, what it means to who they are as human beings. We (teachers) were unaware how becoming relational caring practitioners would impact our lives with learners, and the life of learners, that we were actively and intentionally attending the spirit-as we explored our inner lives (subjective life) human consciousness and "soul spirit". We have been actively discovering what compels us, and orientates our lives [2]. As we have under taken relational inquiry as a way of being with students, we have discovered that our time with students has moved beyond the bare bones of teaching (content) to the more substantive aspects of learning-the personal, and moral development of learners. What we thought of as an approach to re-designing curriculum, brought us to a space where we have become more attentive to the experiences of our life together-we have found a deeper meaning and purpose to our work with students, colleagues, patients and families, and to our very way of being in the world. We have a stronger sense of connection to each other and to the world we live in, a deeper connection to people and place, and to what we are making of our time here together.

As nurse educators we embarked on a spiritual journey with our students, exploring our inner essence, uncovering the path to self-awareness, gently revealing the essential spiritual principles that underpin our teaching practices: (a) life is uncertain and ever-changing; (b) life is cyclical and chaotic; (c) meaning motivates people to strive for idealism; (d) service to others brings joy to the spirit; (e) courage comes from an open heart sensitized to the needs of others; (f) we are all interconnected, inextricably linked through the generations of humanity; $(\mathrm{g})$ human goodness motivates us to great heights (paraphrased, [59], pp. 143-44). Together with our students we collectively shared peace-of-mind and relational acceptance of self and the other essential for spiritual wellness, learning 
and transformation. We have learned as Mayerhoff suggested when we learn together with our students, we "grow in caring" for our students ([60], p. 21).

Perhaps as Hans-Georg Gadamer suggested Erfahrung (experience in German), in our case of cultivating experiences of things inherently important and essential in our lives is about being underway [28]. Furthermore, recognizing that others have gone before us (ancestry or vorfahrung in German), suggests that we become something because of our journey, because of what we have learnt (from our present, past and future) as we are underway [28]. By taking the ontological turn, we found ourselves in the midst of a winter storm, holding on to the metaphorical rope, it was a leap of faith that propelled us beyond the question of what do we believe in as teachers, to what Hartrick Doane and Varcoe propose:

What do you set your heart on? To what vision of right-relatedness between humans, nature and the transcendent are you loyal? What hope and what ground of hope animates you and give shape to your life and to how you move into life? ([2], p. 80).

Relational inquiry has become a means in our lives as learner-teachers of creating coherence between what we hold sacred in our practice-the development of another human being and our work as learner-teachers, and nursing scholars. It has given meaning to our experiences with learners. In the twist and turns this journey continues to provide, at the beginning of each new fall semester, when we invite students into the world of nursing we are humbled as students arrive somewhere between "being invited and finding their way", glimpse the life force that guides their life, that has brought them to this place and time and "set their hearts on and what they hope for" ([2], p. 84). In moments such as these, we sense the meaning of "attending the spirit". It is fall once more, and with our old sweaters wrapped around us we look into the faces of our first year nursing students, sharing the warmth, we also invite them to dig out their old sweaters-and so it begins.

Acknowledgments: The authors would like to thank the many students who have shared their time and wisdom with us. Furthermore, Michelle Spadoni is a AMS Phoenix Fellow and this paper is supported through her studies of compassion, social justice and relational inquiry which is the basis of her fellowship work. "This publication was supported by (2015-2016) AMS Phoenix Fellowship from AMS (Associated Medical Services, Inc.). The content is solely the responsibility of the authors and does not necessarily represent the official views of Associated Medical Services, Inc."

Author Contributions: The authors, Michelle Spadoni and Pat Sevean worked together on all parts of the paper, and both equally contributed to the content and writing.

Conflicts of Interest: The authors declare no conflict of interest.

\section{References}

1. Malidoma Patrice Some. Of Water and Spirit: Ritual, Magic, and Initiation in the Life of an African Shaman. New York: Tarcher/Putnam, 1994.

2. Gweneth Hartrick Doane, and Colleen Varcoe. Family Nursing as Relational. Developing Health-Promotion Practice. Philadelphia: Lippincott Williams \& Wilkins, 2005.

3. Nell Cockell, and Wilfred McSherry. "Spiritual Care in Nursing: An Overview of Published International Research." Journal of Nursing Management 20 (2012): 958-69. [CrossRef] [PubMed]

4. Barbara Pesut. "A Conversation on Diverse Perspectives of Spirituality in Nursing Literature." Nursing Philosophy 9 (2008): 98-109. [CrossRef] [PubMed]

5. Sister M. Simone Roach. The Human Act of Caring: A Blueprint for the Health Professions. Ottawa: Canadian Hospital Association Press, 1992.

6. College of Nurses of Ontario. Competencies for Entry-Level Registered Nurses Practice. Toronto: College of Nurses of Ontario, 2014.

7. Maxine Greene. Landscapes of Learning. New York: Teachers College Press, 1978.

8. Laurie N. Gottlieb, and Bruce Gottlieb. Strengths-Based Nursing Care-Health and Healing for Person and Family. New York: Springer Publishing Company, 2013.

9. Gweneth Hartrick Donae, and Colleen Varcoe. How to Nurse: Relational Inquiry with Individuals and Families in Changing Health and Healthcare Contexts. Philadelphia: Lippincott Williams \& Wilkins, 2015. 
10. Lewis Carroll. Through the Looking-Glass and What Alice Found There. New York: Dover Publications, 1999.

11. Roberto Calasso. The Marriage of Cadmus and Harmony. New York: Knopf, 1993.

12. David W. Jardine. Unable to Return to the God's That Made Them. In Curriculum of Abundance. Edited by David W. Jardine, Sharon Friesen and Patricia Clifford. New York: Routledge Taylor \& Francis Group, 2006, pp. 267-78.

13. Sheryl Reimer-Kirkham, Sonya Grypma, and Landa Terblanche. "Religion and Ethics in Pluralistic Healthcare Contexts." Journal of Christen Nursing 30 (2013): E1-E6.

14. Diana J. Mansell. Forging the Future: A History of Nursing in Canada. Ann Arbor: Thomas Press, 2004.

15. Florence Nightingale. Florence Nightingale Tableaux. New York: The MacMillan Company, 1920.

16. Michelle Spadoni. “Clinical Communication Diary Entry.” Unpublished manuscript. 18 September 1981. Microsoft Word file.

17. Jean Watson. Nursing Human Science and Human Caring a Theory of Nursing. Norwalk: Appleton-Century-Crofts, 1985.

18. Virginia Henderson. "The Nature of Nursing." American Journal of Nursing 64 (1964): 62-68. [PubMed]

19. Patricia Sevean. "Personal Diary Entry." Unpublished manuscript. 30 October 1990. Microsoft Word file.

20. John Dewey. Experience and Education. New York: Touchstone, 1938.

21. Kathryn McPherson. Bedside Matters: The Transformation of Canadian Nursing, 1900-1990. Toronto: Oxford University Press, 1996.

22. Joanne K. Olson, Pauline Paul, Lillian Douglass, Margaret B. Clark, Jane Simington, and Nancy Goddard. "Addressing the Spiritual Dimension in Canadian Undergraduate Nursing Education." Canadian Journal of Nursing Research 35 (2003): 94-107. [PubMed]

23. Betty Neuman. The Neuman Systems Model, 2nd ed. Norwalk: Appleton and Lange, 1989.

24. Sheryl Reimer Kirkham, Barbara Pesut, Heather Meyerhoff, and Rick Sawatsky. "Spiritual Caregiving at the Juncture of Religion, Culture and State." Canadian Journal of Nursing Research 36 (2004): 149-69.

25. Sheryl Reimer-Kirkham. "Nursing Research on Religion and Spirituality Through a Social Justice Lens." Advances in Nursing Science 37 (2014): 249-57. [CrossRef] [PubMed]

26. Alexander W. Astin. "Why Spirituality Deserves a Central Place in Liberal Education." Liberal Education Spring 90 (2004): 34-41.

27. Jennifer A. Lindholm. "Spirituality in the Academy: Reintegrating Our Lives and the Lives of Our Students." About Campus 12 (2007): 10-17. [CrossRef]

28. Hans-Georg Gadamer. Truth and Method, 2nd ed. Translated by Hans-Georg Gadamer. London: Sheed and Ward, 1979.

29. Pamela H. Cone, and Tove Giske. "Teaching Spiritual Care-A Grounded Theory Study Among Undergraduate Nursing Educators." Journal of Clinical Nursing 22 (2012): 1951-60. [CrossRef] [PubMed]

30. Julian Stern, and Sarah James. "Every Person Matters: Enabling Spirituality Education for Nurses." Journal of Clinical Nursing 15 (2006): 897-904. [CrossRef] [PubMed]

31. Mary Elizabeth O'Brien. Spirituality in Nursing: Standing on Holy Ground, 5th ed. Burlington: Jones \& Bartlett Learning, 2014.

32. Bruce W. Speck. "What is spirituality?" New Directions for Teaching and Learning 104 (2005): 3-13. [CrossRef]

33. Larry Dossey. Recovering the Soul: A Scientific and Spiritual Search. New York: Bantam, 1989.

34. Michelle Spadoni, Patricia Sevean, Gweneth Doane Hartrick, Karen Poole, Sandra Cornell, and Lorne McDougal. “Inclusion of Indigenous World Views into Nursing Curricula." In Relational and Responsive Inclusion: Contexts for Becoming and Belonging. Edited by Mere Berryman, Ann Nevin, Suzanne SooHoo and Therese Ford. New York: Peter Lang, 2015, pp. 223-42.

35. Gweneth Hartrick Doane, and Colleen Varcoe. "Relational Practice and Nursing Obligations." Advances in Nursing Science 30 (2007): 192-205. [CrossRef] [PubMed]

36. Michelle Spadoni, Gweneth Hartrick Doane, Patricia Sevean, and Karen Poole. "First-Year Nursing Students-Developing Relational Caring Practice Through Inquiry." Journal of Nursing Education 54 (2015): 270-75. [CrossRef] [PubMed]

37. Gweneth Hartrick Doane, and Helen Brown. "Recontextualizing Learning in Nursing Education: Taking an Ontological Turn." Journal of Nursing Education 50 (2011): 21-26. [CrossRef] [PubMed]

38. David W. Jardine, Sharon Friesen, and Patricia Clifford. "Introduction." In Curriculum in Abundance. Edited by David W. Jardine, Sharon Frieson and Patricia Clifford. New York: Routledge, 2006, pp. 1-12. 
39. Anita J. Skarbek, Sandra Johnson, and Christina M. Dawson. "A Phenomenological Study of Nurse Manager Interventions Related to Workplace Bullying." Journal of Nursing Administration 45 (2015): 492-97. [CrossRef] [PubMed]

40. Janet M. Rankin, and Marie L. Campbell. Managing to Nurse: Inside Canada's Health Care Reform. Toronto: University of Toronto Press, 2006.

41. Nancy Meierdierks Bowllan. “Nursing Students' Experience of Bullying: Prevalence, Impact and Interventions." Nurse Educator 40 (2014): 194-98. [CrossRef] [PubMed]

42. Susan R. Komives, and Dudley B. Woodard. Student Services: A Handbook for the Profession, 4th ed. San Francisco: Jossey-Bass, 2003.

43. Jean T. Walker, Tina Martin, Jill White, Rowena Elliott, Anne Norwood, Carl Mangum, and Lisa Haynie. "Generational (Age) Differences in Nursing Students' Preferences for Teaching Methods." Journal of Nursing Education 45 (2006): 371-74. [PubMed]

44. Helen Brown, and Gweneth Hartrick Doane. "From Filling Buckets to Lighting Fires; Aligning Nursing Education with Nursing Practice." In Teaching Nursing: Student-centred Theories, Models, and Strategies for Nurse Educators. Edited by Lynne E. Young and Barbara L. Paterson. New York: Lippincott Williams and Wilkins, 2007, pp. 97-118.

45. Jack Mezirow, and Edward W. Taylor. Transformative Learning in Practice: Insights from Community, Workplace, and Higher Education. San Francisco: Jossey-Bass, 2009.

46. Patricia Clifford, and Sharon Friesen. "A Curious Plan: Managing on the Twelfth." In Back to the Basics of Teaching and Learning: "Thinking the World Together". Edited by David W. Jardine, Patricia Clifford and Sharon Friesen. New York: Routledge, 2002, pp. 11-30.

47. Pierre Hadot. Philosophy as a Way of Life: Spiritual Experience from Socrates to Foucault. New York: Blackwell, 1995.

48. Richard Rorty. Philosophy and Social Hope. London: Penguin, 1999.

49. Kate C. McLean, and April Thorne. "Identity Light: Entertainment Stories as a Vehicle for Self-Development." In Identity and Story: Creating Self in Narrative. Edited by Dan P. McAdams, Ruthellen Josselson and Amia Lieblich. Washington: American Psychological Association, 2006, pp. 111-27.

50. Dan P. McAdams, Ruthellen Josselson, and Amia Lieblich. "Introduction." In Identity and Story: Creating Self in Narrative. Edited by Dan P. McAdams, Ruthellen Josselson and Amia Lieblich. Washington: American Psychological Association, 2006, pp. 3-10.

51. Richard Wagamese. One Story, One Song. Baldwin: Douglas and McIntyre Ltd., 2011.

52. Arthur W. Frank. The Wounded Storyteller: Body, Illness, and Ethics. Chicago: University of Chicago Press, 1995.

53. Jennifer Lake. Personal Correspondence, 12 November 2013.

54. Gweneth Hartrick. "Relational capacity: The Foundation For Interpersonal Nursing Practice." Journal of Advanced Nursing 26 (1997): 523-28. [CrossRef] [PubMed]

55. John Caputo. Radical Hermeneutics: Repetition, Deconstruction, and the Hermeneutic Project. Indianapolis: Indiana University Press, 1987.

56. Josephine Paterson, and Loretta Zderad. Humanistic Nursing Theory. New York: John Wiley \& Sons, 1976.

57. Gweneth A. Hartrick. "Transcending the Limits of Method: Cultivating Creativity in Nursing." Research and Theory for Nursing Practice: An International Journal 16 (2002): 53-62. [CrossRef]

58. Emma Policastro, and Howard Gardner. "From Case Studies to Robust Generalizations: An Approach to study of Creativity." In Handbook of Creativity. Edited by Robert J. Sternberg. New York: Cambridge University Press, 1999, pp. 213-25.

59. Verna C. Pangman, and Clare Pangman. Nursing Leadership from a Canadian Perspective. Philadelphia: Lippincott Williams and Wilkins, 2010.

60. Milton Mayerhoff. On Caring. New York: Harper and Row Publishers, 1971.

(C) 2016 by the authors; licensee MDPI, Basel, Switzerland. This article is an open access article distributed under the terms and conditions of the Creative Commons by Attribution (CC-BY) license (http://creativecommons.org/licenses/by/4.0/). 